\title{
THE ANALYSIS OF THE QUALITY INFLUENCING FACTORS OF REGIONAL GOVERNMENT FINANCIAL REPORTS AND THE IMPLICATION TOWARDS THE GOVERNMENT EMPLOYEE PERFORMANCE OF LAMPUNG PROVINCE GOVERNMENT
}

\author{
Raisa Lestari1) , Einde Evana2) , Agrianti Komalasari 3) \\ Master of Accounting Science \\ Accounting Major, Faculty of Economy and Business, University of Lampung \\ Faculty of Economics and Bussines, University of Lampung,Indonesia
}

\begin{abstract}
This study aims to examine the relationship between the influence of human resource capacity, the application of government internal control systems and the use of information technology to the quality of local government financial reports, and their implications for employee performance. The study was conducted among 107 employees who worked in the accounting department of the Regional Agency for Financial Management and Assets and the Regional Revenue and Asset Management Service, who had responsibilities and main functions in the preparation of financial reports of district governments of Lampung Province. The data analysis technique used in this study is the SEM (Structural Equation Model) method using the AMOS program as a research tool. This research shows empirical evidence that human resource capacity, the application of government internal control systems and the use of information technology have a positive effect on the quality of local government financial reporting, this study found. also successfully demonstrated that there is a positive influence on the quality of local government financial statements on employee performance.
\end{abstract}

Keywords: Human Resource Capacity, Implementation Of Government Internal Control Systems, Use Of Information Technology, Quality Of Local Government Financial Reports, Employee Performance

Copyright (C) 2020, International Journal of Economics, Business and Entrepreneurship | IJEBE | FEB-UNILA

\section{INTRODUCTION}

According to Government Regulation No. 71 of 2010, if the information contained in the Regional Government Financial Reports fulfills the characteristic criteria, the regional government is able to realize transparency and accountability in regional financial management. The information contained in the financial reports have to be proper with established standards, if it is not proper it will result in regional losses, potential lack of income, administrative weakness, inefficiency and ineffectiveness (Evicahyani and Setiawina, 2016).

In order to realize these objectives, the government compiled Government Accounting Standards (SAP) set out in Government Regulation Number 24 of 2005 concerning cash-based Government Accounting Standards to accruals as a transitional period towards full accrual-based accounting which was later replaced with PP Number 71 of 2010 concerning Accrual-based Government Accounting Standards. An accrual basis is an accounting basis that recognizes transactions and other events as they occur (Hardani, 2018). Beside, accrual-based financial reports provide 
information on government operational activities, evaluation of efficiency and effectiveness, laso compliance with regulations. Accrual-based accounting is also believed to provide better measurement, timely recognition, and disclosure of future obligations. Financial information generated on an accrual basis can reduce opportunities for fraud in relation to performance measurement, and support the realization of public sector transparency and accountability (Sudarsono, 2017).

Another matter that affects the quality of financial reports is the Internal Control System (SPI). According to Government Regulation No. 60 of 2008 the internal control system is an integral process in actions and activities conducted continuously by the leader and all employees to give adequate confidence in the achievement of organizational goals through effective and efficient activities, reliability of financial reporting, security of state assets and obedience to laws and regulations. In addition, a factor influencing the quality of regional financial reports is the use of information technology. Accounting information systems include the use of information technology to provide information for users. Computers are used in all types of information systems. Information technology includes computers, also includes other technologies used to process information (Bodnar and Hopwood, 2010).

Several researches have been conducted to find out the factors that influence the regional government financial report quality including Andriani (2010), Delanno and Deviani (2013), Anggraeni and Riduwan (2014) and Manimpurung et al (2018). But, this research only takes the factor of human resource capacity, utilization of information technology, and government internal control systems. The difference between this study and previous research is that it does not take accounting factors, because accounting comprehension is part of the human resources capacity. Human resource capacity is the ability of human resources to do their duties and responsibilities. In preparing financial reports, accounting comprehension is part of the human resource ability.

Moreover, this research adds employee performance variables that are expected to prove whether the regional government financial report quality has implicated to the employee performance, due to the use of information technology that will support the qualified financial report information, this qualified financial report information is the basis for employees in decision making, especially top level employees and can be used as a benchmark for measuring performance (Primasari, 2017). This research focuses on the Regency/City Government in Lampung Province, in purpose that the Regency/City Government in Lampung has the spirit to move to a more transparent online data provider system, and currently has a plan to have a program that aims to compile all information, so Lampung Province only has a legal source of data. This data has to be used by Lampung government agencies, as well as institutions outside the Regional Government. Compiled data will reduce the information misusing possibility and become a basis for more valid policy making (humasprotokol. lampungprov.go.id, 2019).

\section{Problems}

Lampung Provincial Government along with 12 Regency/City Governments obtain a financial opinion of Fair Unqualified Financial (WTP) opinion from RI Supreme Audit Agency (BPK). The opinion given is an evaluation of the 2017 Regional Government Financial Report (LKPD). 
Meanwhile, for the regional government that have not yet obtained WTP opinion from BPK, it shows that regional government financial reporting is not yet fully believed to be reasonable by the BPK due to various factors, the BPK also found weaknesses in the internal control system of the Regional Government Financial Report (BPK Representative of Lampung Province, 2018). Given these problems, then does the human resource capacity, the application of government internal control systems and the use of information technology influence the regional government financial report quality, and does the regional government financial report quality influence employee performance?

This research aims to provide empirical evidence about :

1) study and find out the influence of human resource capacity (HR), the application of government internal control systems (SPIP) and the use of information technology on the regional government financial report quality.

2) study and find out the influence of the regional government financial reports quality on employee performance.

\section{Theoretical Framework}

\section{Financial Report Quality}

The financial report quality can be considered qualified if they meet the qualitative characteristics of financial report contained in Government Regulation Number 71 of 2010 concerning SAP, which are relevant, reliable, comparable, and understandable. According to Jonas and Blanchett (2000) the financial report quality is complete and transparent information, designed not to mislead users. So, the financial report can be compared with the financial report of the previous period, then it has be arranged based on established accounting standards.

The financial report qualitative characteristics are normative measures that need to be realized in accounting information so that it can meet the aims. In Government Regulation Number 71 of 2010, it states the government financial report qualitative characteristics, which are:

1) Relevant

Financial report can be considered to be relevant if the information contained in them can influence user decisions by helping them evaluate past or present events and predict the future, as well as correcting the evaluation result in the past.

2) Reliable

Reliable is information in financial report that is free from misleading notions and material errors, truly presents every fact, and can be verified.

3) Comparable

The information contained in the financial report will be more useful if it can be compared with the previous period financial report or other finanicial report entities in general.

4) Understandable

The information presented in the financial statements can be understood by users and stated in form and term that are adjusted to the user comprehension limits.

5) Financial report is presented as suitable as the guidelines for LKPD arrangement

\section{Human Resource Capacity}

Human Resources Capacity is the human resource ability to do the tasks and responsibilities given to them with adequate education, training and experience. So it can be concluded that the 
human resource capacity is the human resource ability to do their duties and responsibilities in the organization with adequate education, training and experience to achieve organizational goals effectively and efficiently.

\section{Government Internal Control System}

Internal Control System is an integral process of actions and activities conducted continuously by the leader and all employees to provide adequate confidence in achieving organizational goals through effective and efficient activities, financial report reliability, security of state assets, and compliance with the laws and regulations. The Government Internal Control System (SPIP) is an integral part of the government accounting system. In Government Regulation No. 60/2008 concerning the Government Internal Control System (SPIP) it is explained that SPIP is an Internal Control System that is conducted comprehensively within the central government and regional governments.

\section{Information Technology Utilization}

Information technology is a general form that describes any technology that help produce, manipulate, store, communicate, and or convey information. According to Surastiani and Handayani (2015), Information technology includes computer (mainframe, mini, micro), software, database, network (internet, intranet), electronic commerce, and other types that relate to technology.

\section{Employee Performance}

Performance is the work that can be achieved by a person or group of people in an organization, as suitable as their respective authorities and responsibilities to achieve the objectives of the organization legally, does not violate the law and appropriate with morals and ethics. Robbins (2013) states that performance is a contribution made by members of the organization to achieve organizational goals. While Hall (2004) to a worker performance in a situationl way, depending on the internal condition (personality and emotion) and external factor which covers organization individual in doing work. This research defines employee performance as employee skills in conducting managerial activities such as planning, investigation, coordination, supervision, staffing arrangements, negotiation and representation (Hall, 2004).

\section{Research Design}

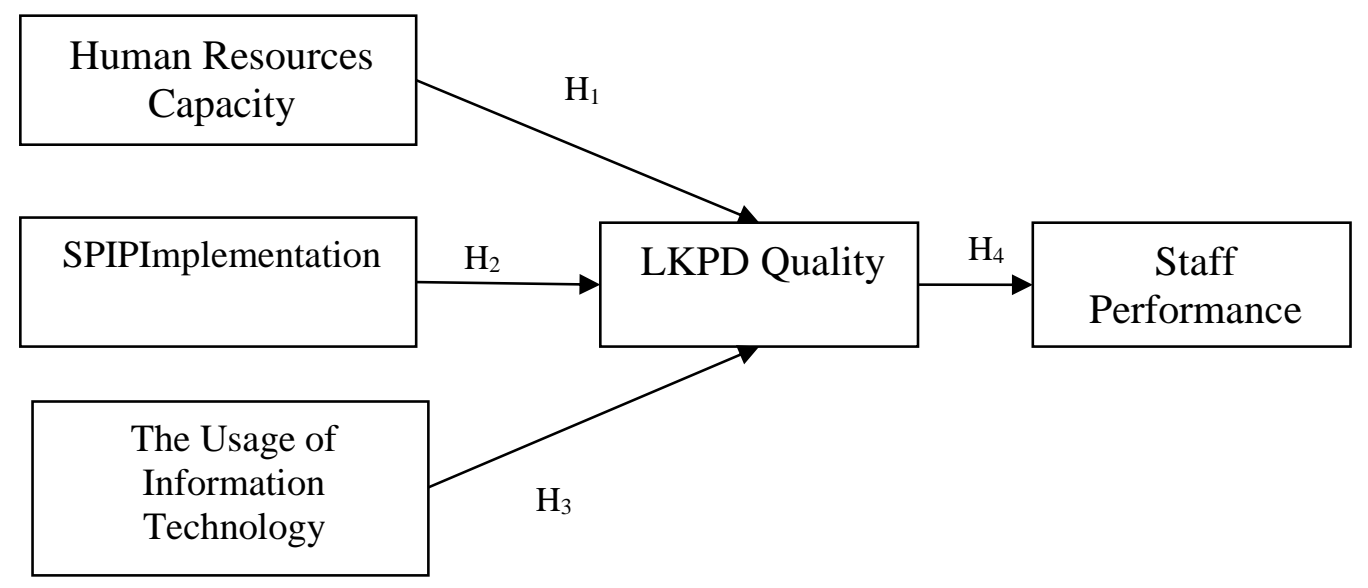

Figure 1. Mind-Mapping 
Hypothesis:

H1: HR Capacity influence positively toward LKPD quality

H2: Internal control system influence positively toward LKPD quality

H3: Information technolody utilization influence positively toward LKPD quality

H4: LKPD quality influence positively toward Employee Performance

\section{RESEARCH METHODS}

Population used by researcher in this research was accounting staff in Regional Financial and Asset Management Agency (BPKAD) and the Regional Financial and Asset Management Office (DPPKAD) in Regency/City in Lampung Province, covering to 15 Regencies/Cities. The employee was chosen based on purposive sampling (determined criteria). The sample selection criteria in this research were as follows:

The criteria used in sampling were:

1. Employees who work in accounting at BPKAD/DPPKAD of Regency/City in Lampung Province.

2. Working length in the same field for at least 1 (one) year.

Research Variable Operational:

1. Human Resource Capacity is the ability of human resources to conduct functions and authorities in the organization with adequate education, training and experience to achieve organizational goals effectively and efficiently (Yosefrinaldi, 2013). Have indicators of educational background, training and responsibility (Alimbudiono et al, 2004, Delano, dand Deviani, 2013).

2. Government Internal Control System is a process designed by management to provide adequate assurance or confidence in the achievement of organizational goals through effective and efficient activities, financial reporting reliability, security of state assets, and compliance with laws and regulations (Permendagri No.13 of 2006). Has indicators: control environment, risk assessment, control activities, information and communication, and supervising (PP No. 60 of 2008, and Surastiani and Handayani, 2015).

3. Information Technology Utilization is the level of integration of information technology in the accounting tasks implementation (Widyaningrum, and Rahmawati, 2010), have indicators of progress in communication information, web development and internet technology, changes in reporting systems, adequate facilities and infrastructure, regular maintenance (PP Number 65 of 2010, Surastiani and Handayani, 2015).

4. Regional Government Financial Report Quality is the ability of the information presented in the financial report can be understood, and meets the needs of users in decision making, free from misleading notions, material errors and can be relied upon, so the financial report can be compared with previous periods, have indicators of relevant, reliable, comparable, understandable and as suitable as the guidelines for LKPD arrangement (PP No. 71 of 2010, Surastiani and Handayani, 2015).

5. Employee Performance is a level of success and the main factor of employees in an organization or institution in order to achieve an effective and efficient level (Simanjuntak, 2005), have indicators of Quality, Quantity, Punctuality, Independency and Cooperating ability (Simamora, 2006) 
The data analysis technique used in thi research was SEM (Structural Equation Model) method. According to Ferdinand (2011), SEM was a data analysis tool or technique that consists of two basic stages which were the measurement model stage through the Confirmatory Factor Analysis and the structural equation model stage. The main objective was to test the model suitability (fit) to the valid data. The structural equation model was different from other multivariate analysis techniques. SEM only using input data in the variant or covariant matrix or correlation matrix. While the model estimation technique used was maximum likehood estimation with the AMOS program. When the model had been accepted, it could be considered to do a modification of the model to improve the theoretical explanation or goodness of fit.

If the model is modified, then the model must be estimated with separate data (cross validated) before the modification model is accepted, with the following model:

$\eta=\Gamma \xi+\beta \eta+\zeta$

Description

$\eta \quad$ : endogenous latent construct matrix

$\beta \quad$ : endogenous variable matrix coefficients

$\xi \quad$ : exogenous latent construct matrix

$\Gamma \quad$ : coefficient of the exogenous variable matrix

$\zeta \quad$ : inner matrix residual model

\section{RESULTS AND DISCUSSION}

According to the preliminary observations, it is known that the total population is 125 employees. In the process of sampling, questionnaires were distributed on May 24, 2019 to June 14, 2019, and 107 questionnaires were obtained which could be used as research data. Here are the results of the questionnaire distribution:

Table 1. Research Questionnaire Distribution

\begin{tabular}{|l|c|c|}
\hline \multicolumn{1}{|c|}{ Description } & Total & $\begin{array}{c}\text { Percentag } \\
\text { e }\end{array}$ \\
\hline Questionnaire Distribution (Population) & 125 & $100 \%$ \\
\hline Incomplete/Missing Questionnaire & $(18)$ & $(14 \%)$ \\
\hline Questionnaire That Can Be Processed & 107 & $86 \%$ \\
\hline N Samples $=107$ & \multicolumn{2}{|l}{} \\
\hline Respondents' Rate $=86 \%$ &
\end{tabular}

\section{Structural Equation Modelling (SEM)}

In this research, researchers used Structural Equation Modeling (SEM) contained in the Amos program where this method tests together with the model consisting of independent variables and dependent variables. After passing validity and reliability testing, the next step is to analyze the suitability of the data with the overall model or in Amos called Goodness of Fit (GOF). This test will evaluate whether the resulting model is a fit model or not. After estimating the structural model, the following calculation results are obtained: 
Table 2. Measurement Model Test

\begin{tabular}{|c|c|c|c|}
\hline $\begin{array}{c}\text { Goodness of Fit } \\
\text { Indeks }\end{array}$ & Cut of Value & $\begin{array}{c}\text { Analysis } \\
\text { Result }\end{array}$ & $\begin{array}{c}\text { Model } \\
\text { Evaluation }\end{array}$ \\
\hline Chi Square & expected small & 102,228 & Good \\
\hline Probability & $>0.05$ & 0.060 & Good \\
\hline GFI & $>0.90$ & 0.867 & Marginal \\
\hline AGFI & $>0.90$ & 0.850 & Marginal \\
\hline IFI & $>0.90$ & 0.982 & Good \\
\hline TLI & $>0.90$ & 0.971 & Good \\
\hline CFI & $>0.90$ & 0.982 & Good \\
\hline NFI & $>0.90$ & 0.780 & Marginal \\
\hline RMSEA & $<0.08$ & 0.060 & Good \\
\hline
\end{tabular}

Table 2 concluded the results of the overall model fit test, there are 3 GOF sizes indicating a moderate fit (marginal fit), and 5 GOF sizes showing a good fit, so it can be concluded that the overall fit of the model is good (good fit).

\section{Hypothesis Test}

The research hypothesis test is conducted based on the analysis results of the causality relationship between the research constructs, and presented as follows:

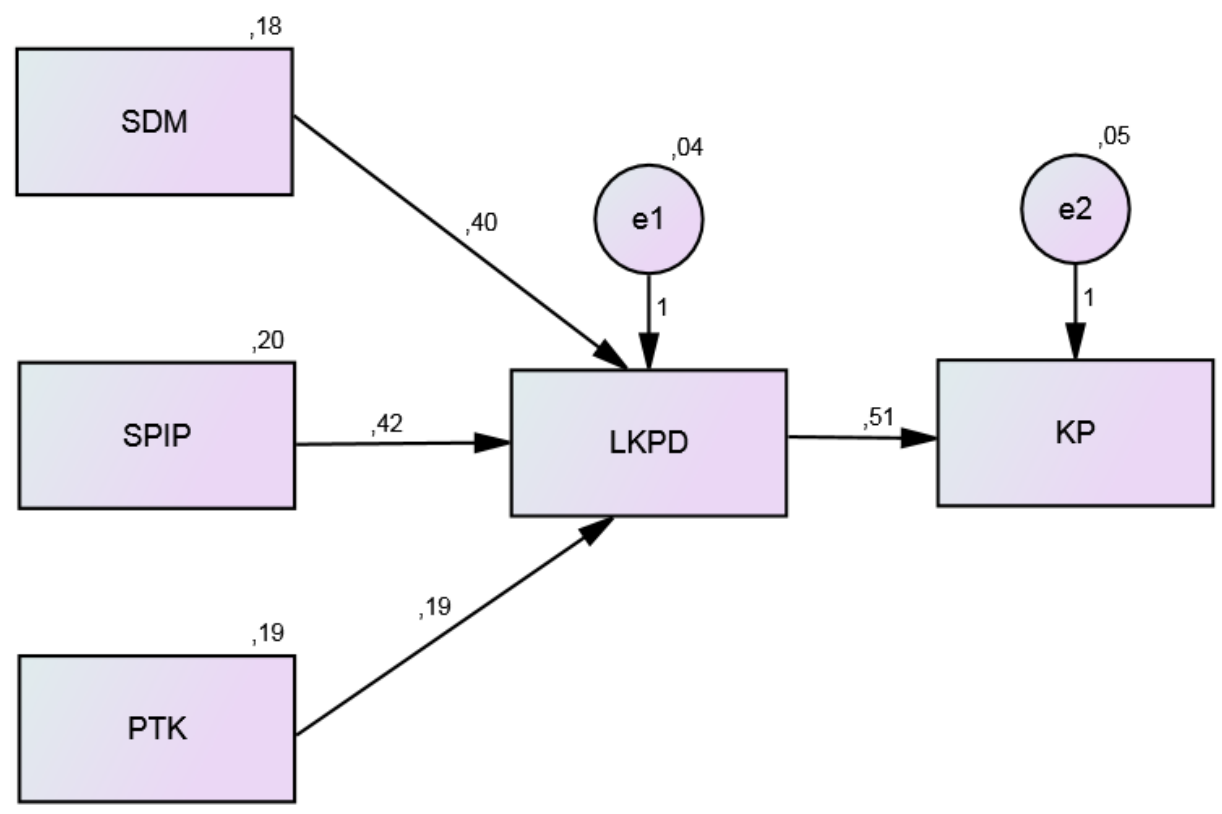

Figure 2. Hypothesis Test Result

According to Figure 2 Research hypothesis are tested based on the results of the analysis of causality relationships between research constructs, as presented in the following table: 
Table 3. Hypothesis Test Result

\begin{tabular}{|lll|c|c|c|c|c|}
\hline \multicolumn{2}{|c|}{ Description } & $\begin{array}{c}\text { Estimat } \\
\text { e }\end{array}$ & S.E. & C.R. & P & Result \\
\hline SDM & ? & LKPD & 0,404 & 0,045 & 8,962 & 0,000 & Accepted \\
\hline SPIP & ? & LKPD & 0,424 & 0,042 & 10,068 & 0,000 & Accepted \\
\hline PTK & ? & LKPD & 0,192 & 0,043 & 4,449 & 0,000 & Accepted \\
\hline LKPD & ? & KP & 0,509 & 0,067 & 7,642 & 0,000 & Accepted \\
\hline
\end{tabular}

Testing this hypothesis is by analyzing the value of C.R and P value of the results of data processing, compared with the statistic restrictions required, it is above 1.96 for CR values, C.R value shows the critical ratio value obtained from the estimated value divided by the standard error (S.E). It is more significant as the higher of C.R value. In addition, the required statistical limit is below 0.05 for the $\mathrm{P}$ value. If the results of data processing indicate a value that meets these requirements, the proposed research hypothesis can be accepted. While the estimated value reflects the Regression Coefficient on the unstandardized estimate, then the SE value or Standard Error is another term Standard Error of the Mean that is the standard deviation of the Mean of each sample (Sampling Means) with the Population Mean. Referring to the overall model final testing results, the model equation can be written in the form of Structural Equation Model (SEM) as follows:

$\mathrm{Y} 1=0,404 \mathrm{X} 1+0,424 \mathrm{X} 2+0,192 \mathrm{X} 3$

$\mathrm{Y} 2=0,509 \mathrm{Y} 1$

\section{Description}

$$
\begin{array}{ll}
\text { Y1 } & \text { = Regional Government Financial Report Quality (LKPD) } \\
\text { Y2 } & \text { = Employee Performance (KP) } \\
\mathrm{X} 1 & \text { = Human Resource Capacity (SDM) } \\
\mathrm{X} 2 & \text { = Government Internal Control System (SPIP) } \\
\mathrm{X} 3 & \text { = Information Technology Utilization (PTK) }
\end{array}
$$

Coefficient of determination (R2) resulting from the structural equation model to show how great the influence exerted on the dependent variable of the independent variable associated with the path of each influence shows the following results: 
Table 4. Coefficient of Determination (Squared Multiple Correlation)

\begin{tabular}{|c|c|}
\hline Variabel & Estimate \\
\hline LKPD & 0,655 \\
\hline KP & 0,355 \\
\hline
\end{tabular}

The calculation results above show that in this model the variables that together give influence to employee performance (KP) are 35.5\%, based on the contribution of one variable, which is Regional Government Financial Statements Quality (LKPD), while the influence of LKPD of $65.5 \%$ is based on the contribution of 3 variables, which are the human resources (SDM) capacity, the application of the government internal control system (SPIP) and information technology utilization (PTK). This means that the proportion of the given influence by the independent variables on the dependent variable in this research contributed to a significant influence, while the rest is influenced by other factors not tested in the model.

\section{Discussion}

\section{The Influence of Human Resource Capacity towards Quality of LKPD}

Based on assumption of stewardship theory which states that manager will try to manage resource maximally and take the best decision for organization interst and work based on thinking that profit (fulfillment of needs) of manager or steward and owner or principal comes from company with strong organization and economy. Employees who have high HR capacity will be able to understand accounting logic well and then use their knowledge and understanding in preparing financial reports in accordance with accounting principles and established rules so that the resulting financial reports are free from misstatement (reliably) and quality. In addition, experienced human resources will be able to work quickly, so that the resulting financial reports can be timely (relevant) and quality.

Result of the questionnaire distribution shows that most of the employees in accounting department in Regional Financial and Asset Management Agency (BPKAD) and Regional Financial and Asset Management Revenue Agency (DPPKAD) in Regencies/Cities in Lampung Province, have work period more that 5 years also most of them have Bachelor degree. That result provides illustration that most of the respondents are employees who have quality, because it needs human resource which understand and competent in the implementation of government financial accountancy also organization about government. Skill of human resource can play role in resulting quality information. Competency of human resource can be seen from educational background, training that have been followed, amd from skills that is stated in the implementation of duties.

Research result also provides evidence that most of the respondets have good perception towards human resource who work in accounting department in BPKAD/DPPKAD in Regencies/Cities of Province. The right number of human resources with good 
competency will affect the reliability of reginal financial report, that capacity and competency of human resource is connected to each other. If human resource that will implement accounting system do not have the required quality, it will cause resistance in the implementation of accounting function, and at the end, accounting information as product of accountancy system, its quality becomes poor. The information resulted becomes information which is less or have no value, such as reliability.

\section{The Influence of Implementation of Government Internal System towards Quality of LKPD}

Government Internal Management System (SPIP) is a process designed by management to gives sufficient guarantee or confidence for the achievement of organization purpose through more effective and efficient activities, reliability of financial reporting, securing state assets, and compliance to laws and regulations. An effective Government Internal Control System will protect the organization from human weaknesses, reduce errors and irregularities that will occur, so that the information resulted in financial report can fulfill the qualitative characteristics of financial reports and will increase stakeholder confidence.

Indicator to measure SPIP variable is based on PP No. 60 of 2008, which is management environment, risk assessment, management activities, information and communication and monitoring. Based on data of respondent answers, the average respondent answers are agree for each assessment indicator, which means that the five management elements have been implemented effectively. This shows that SPIP in Regencies/Cities in Lampung Province is good.

Internal management is a manner to direct, supervise, and measure the resources of organization, and has an important role in the prevention and detection of fraud. The application of adequate internal control will provide adequate confidence in the quality or reliability of financial report information, and will increase stakeholder confidence. The results of this research are in line with research by Surastiani and Handayani (2015) which proves that the internal control system has a positive effect on the quality of regional government financial report information.

\section{The Influence of Information Technology towards Quality of LKPD}

Utilization of Information Technology is behavior of using information technology to finish tasks and improve performance. Computer and network are information tehnology used in arrangement of financial report (Winidyaningrum and Rahmawati, 2010). Result of research from Delanno and Deviani (2013) proves that the utilization of computer and network will help to fasten the process of transaction data and presentation of financial report so that financial report do not lose the value of information that is timeliness. Timeliness of financial reporting will cause the value of information to be relevant and financial statements to be of quality.

Based on descriptive data, it shows that technology utilization in SKPD of Regencies/Cities in Lampung Province is high, most of the respondent asnwers are in scale range 4 and 5. According to respondent assessment, accountancy process since beginning of transaction until the making of financial report has been conducted with 
computer. Computer network which installed has been utilized maximally in work unit as connector in data delivery or information needed. In addition, based on researcher observation, it can be known that since the implementation of APBD Fiscal year 2019, The change of APBD Fiscal year 2019, Government of Lampung Province has used application of Regional Financial Budgeting Planning System (SIPPKD) according to Government Policy (PP) No 12 of 2019 which is built, supervised, by Korsupgah KPK Team. The use of the SIPPKD application provided a change in understanding from the implementing apparatus. For this reason, in order to strengthen the implementation of the SIPPKD application in the Lampung Provincial Government, it is necessary to conduct a review of the SIPPKD application to the Regional Government Apparatus involved in the management of regional finances.

The utilization of information technology is viewed as really help in producing quality financial report, with the rapid development of information technology also wide potention to its utilization, then can open opportunities to various parties to access, manage, and utilize regional financial information in quick and accurate manner. This result is in line with Darwanis and Mahyani (2009) also Delanno and Deviani (2013) which proves that partially, information technology utilization variable influences the increase of reliability of regional government financial report.

\section{The Influence of LKPD Quality towards Employee Performance}

Result of this research is in line with research conducted by Spencer et al (2013) which proves that characteristic of quality information in financial report has positive and significant influence towards managerial performance. According to stewardship theory, in principle, accountancy is self management tool, as tool for managerial activity reporting towards management of human resource and finance. With limitation, the owner of human resource hands trustworthy of resource management to other parties. Better quality of financial report will stimulate employees to find out financial report, the employees can know and ensure that all processes are running well (Thorton, 2009).

This financial report also becomes reference in supporting planning aspect in the future, so that performance of each employee will be better. The implementation of good accountancy by government institute and optimal supervision towards quality of government institute financial report is expected to be able to produce quality financial report so that performance of implementation of government business will be optimal, with quality of high accountancy information characteristic, then employees will have positive views and try to do the best for the interest of organization.

Performance in this research is related to the achievement of series of duties by regional government employees (Simamora, 2006). The higher performance involves combination of the improvement of efficiency, improvement of effectiveness, improvement of productivity, and improvement of quality. Performance will be achieved if individual can fulfill their needs in implementing and finishing duties, also performance will be effective if based on policy of quality financial report. Employee with understanding of purpose of their job and know how to achieve that, can give assessment and award to their jobs so that it can be said that it can give evaluation with purpose to make the next job is better. 


\section{CONCLUSION}

Result of this research provides conclusion as follows:

1.Based on result of testing, this is proven that there is positive influence to implementation of human resource capacity towards quality of regional government financial report.

2.Based on testing result, it is proven that there is positive influence to implementation of intern management system towards quality of regional government financial report, so that hypothesis which stated that "Intern management system has positive influence towards quality of LKPD”, is accepted.

3.Based on testing result, it is proven that there is positive influence for the usage of information technology towards quality of regional government financial report, so that hypothesis which stated that "The utilization of information technology has positive influence towards quality of LKPD", is accepted.

4.Based on result of testing it is proven that there is positive influence of regional government financial report towards employees performance, so that hypothesis which stated that "Quality of LKPD has positive influence towards Employee Performance", is accepted.

\section{RECOMMENDATION}

\section{Recommendation For Academics}

Based on this research result, next can be proposed a suggestion which is expected will be beneficial for academics as follows:

1.In the next research, other free variables should be added, such as transparency, and other variables which affect the quality of financial report. Also, can add other moderating variables such as, external factor, financial supervision, and other variables.

2.In addition, data collection in the next research is expected not only limited to distribution of questionnaire only, but can also conducted through interviews.

\section{Recommendation For Regional Government}

Research result concludes that there is Influence of human resource capacity towards quality of local government financial report, therefore, it is suggested especially to Local Financial and Asset Management Agency (BPKAD) and Regional Financial and Asset Management Revenue Agency (DPPKAD) in Regencies/Cities in Lampung Province to improve human resource competency. Quality human resource is needed to produce quality financial report.

\section{Limitations}

Limitations in this research and have possibility to affect the research result are: 
1.Sample taken by researcher is public sector organization, so that the conclusion of this research not necessarily the same if the research is conducted in organization of other sectors. In addition, from 125 population, this research only obtained 107 samples that can be used as respondents.

2.This research is conducted by using data collection with questionnaire which refers to the previous research which is too general and not in accordance with characteristic of public sector in other regions

3.Measurement all variables in this research is based on respondent perception, so that it can cause problem is respondent perception is not in accordance with the real condition.

\section{REFERENCE}

Alimbudiono., Sandra, Ria dan Fidelis, Arastyo Andono. 2004. Kesiapan sumber Daya Manusia Sub Bagian Akuntansi Pemerintah Daerah "XYZ" dan Kaitannya Dengan Pertanggungjawaban Keuangan Daerah Kepada Masyarakat: Renungan Bagi Akuntan Pendidik. Jurnal Akuntansi dan Keuangan Sektor Publik. Vol. 05 No. 02. Hal. 18-30.

Anggraeni, D.T. dan Riduawan, A. 2014. Faktor-faktor yang mempengaruhi Keterandalan Pelaporan Keuangan Daerah (Studi pada SKPD di Kabupaten Sidoarjo), Jurnal Ilmu \& Riset Akuntansi Vol.3 No. 3.

Bastian, Indra. 2010. Akuntansi Sektor Publik Pengantar Edisi Ketiga, Penerbit Erlangga : Salemba Empat

Bodnar, H.G. dan Hopwood, W.S. 2010. Sistem Informasi Akuntansi. Buku I. Edisi Ke-6. Penerjemah Amir Abadi Jusuf dan Rudi M. Tambunan. Jakarta: Salemba Empat.

BPK Perwakilan Provinsi Lampung, 2018

Delanno, Galuh Fajar dan Deviani. 2013. Pengaruh Kapasitas SDM, Pemanfaatan TI dan Pengawasan Keuangan Terhadap Nilai Informasi Pelaporan Keuangan Pemerintah Daerah. Jurnal WRA. Vol.1 No.1 April 2013.

Ghozali, Imam. 2014. Structural Equation Modeling: Metode Alternatif Dengan Partial Least Square (PLS). Edisi 4. Semarang: Badan Penerbit Universitas Diponegoro.

Halim, Abdul. 2016. Manajemen Keuangan Sektor Publik Problematika Penerimaan dan Pengeluaran Pemerintah. Jakarta: Salemba Empat.

Hall, M. 2004. The effect of Comprehensive Performance Measurement Systems on Role Clarity, Psycological, Empowerment and Managerial Performance. Global Management Accounting Research Symposium. Available on www. ssrn.com.

Hardani, Yuliana Wahyu Eko. 2018. Peranan BPK dalam Meningkatkan Akuntabilitas dan Transparansi LKPD. BPK-RI. Jakarta. 20 September 2018.

Hery. 2016. Analisis Laporan Keuangan. Integrated and Comprehensive Edition. Grasindo. Hal 3. Ikatan Akuntan Indonesia. 2015. Standar Akuntansi Keuangan.

Indriasih, D. 2014. The Effect of Government Apparatus Competence and the Effectiveness of Government Internal Control Toward the Quality of Financial Reporting in Local Government. Research Journal of Finance and Accounting. Vol. 5, No.20 ISSN 2222-2847.

Kurniawan, Marindo., Fajri, Nurul., Cherlanda, M Dicky dan Saleh, Sondy. 2019. Meretas Birokrasi Konvensional. Balitbangda Provinsi Lampung. 
Mahmudi. 2018. Akuntansi Sektor Publik. Edisi Revisi. UII Press. Hal 251.

Mardiasmo. 2009. Akuntansi Sektor Publik. Yogyakarta: Penerbit ANDI.

Primasari, Dona. 2017. Pengaruh Implementasi Sistem Informasi Keuangan Daerah dan Kinerja Pegawai. Akuntabilitas: Jurnal Ilmu Akuntansi. Volume 10 (1), April 2017.

Robbins, Stephen P. 2013. Perilaku Orgnisasi, Edisi Kesepuluh. PT. Indeks Kelompok Gramedia. Jakarta.

Sari, S, P dan Witono, B. 2014. Keterandalan dan ketepatwaktuan pelaporan keuangan daerah ditinjau dari sumber daya manusia, pengendalian internal dan pemanfaatan Teknologi informasi. Sancall. Hal. 418-425.

Simamora. 2006. Manajemen Sumber Daya Manusia. Penerbit STIE YKPN: Yogyakarta.

Sudarmanto, 2014, Kinerja dan Pengembangan Kompensasi SDM, Pustaka pelajar, Yogyakarta

Sudarsono, Galih. 2017. Pengaruh Sistem Pengendalian Intern, Kompetensi Sumber Daya Manusia dan Penerapan Sistem Akuntansi Keuangan Daerah Terhadap Pelaporan Keuangan Pemerintah Daerah Kab. Grobogan. E-Jurnal Undip. Vol. 6, No. 2, 2017. Hal. 1-10.

Sugiono.2015. Metode Penelitian Kuantitatif Kualitatif dan R \& D. Bandung

Surastiani, Dyah Puri dan Handayani, Bestari Dwi. 2015. Analisis Faktor-Faktor Yang Mempengaruhi Kualitas Informasi Laporan Keuangan Pemerintah Daerah. Jurnal Dinamika Akuntansi. Vol. 7, No. 2, September 2015. Halaman 139-149.

Widyaningrum, Celviana dan Rahmawati. 2010, "Pengaruh SDM, dan Pemanfaatan Teknologi Informasi terhadap Keterandalan dan Ketepatwaktuan Pelaporan Keuangan Pemerintah Daerah dengan Variabel Intervening Pengendalian Intern Akuntansi, Studi empiris di Pemda Subosukawonosraten". Simposium Nasional Akuntansi XIII Purwokerto.

Yosefrinaldi. 2013. "Pengaruh Kapasitas Sumber Daya Manusia Dan Pemanfaatan Teknologi Informasi Terhadap Kualitas Laporan Keuangan Pemerintah Daerah Dengan Variabel Intervening Sistem Pengendalian Intern Pemerintah." Jurnal Fakultas Ekonomi Universitas Negeri Padang. 